\title{
A Review of Bayesian Networks as a Participatory Modeling Approach in Support of Sustainable Environmental Management
}

\author{
Meike Düspohl ${ }^{1}$, Sina Frank ${ }^{1} \&$ Petra Döll ${ }^{1}$ \\ ${ }^{1}$ Institute of Physical Geography, Goethe University Frankfurt, Germany \\ Correspondence: Meike Düspohl, Institute of Physical Geography, Goethe University Frankfurt, P.O. Box 1119 \\ 32, Frankfurt am Main 60054, Germany. Tel: 49-069-798-40220. E-mail: duespohl@em.uni-frankfurt.de
}

Received: August 27, 2012 Accepted: October 24, 2012 Online Published: November 8, 2012

doi:10.5539/jsd.v5n12p1 URL: http://dx.doi.org/10.5539/jsd.v5n12p1

\begin{abstract}
To support sustainable environmental management, uncertain knowledge about complex human-environment-systems from both inside and outside of academia needs to be integrated. Bayesian Network (BN) modeling is a promising method to achieve this, in particular if done in a participatory manner. Based on a review of 30 cases of participatory BN modeling of environmental problem fields, and of three guidelines, we summarize recommendations for $\mathrm{BN}$ modeling with stakeholder involvement. In addition, strengths and limitations of BNs are synthesized. We found that BNs were successfully applied for knowledge integration and identification of sustainable management strategies within participatory processes. Due to many favorable characteristics, BNs have the potential to become a core method of transdisciplinary knowledge integration in environmental management.
\end{abstract}

Keywords: Bayesian Networks, transdisciplinary research, participatory modeling, stakeholder involvement, environmental management, knowledge uncertainty

\section{Introduction}

Typically, sustainability-oriented environmental management and planning deals with problem fields that are characterized by (1) a significant degree of uncertainty or even ignorance and (2) different and equally legitimate perspectives on what is pertinent and what is best. This prevents identification of "optimal" management strategies based on purely scientific evidence (Giampietro, 2002). Examples include integrated water resources management, climate change mitigation and adaptation, and approaches for dealing with man-made organic compounds that are potentially toxic for humans and other biota. For integrated water resources management that aims at optimizing ecosystem services, for example, there may be a need to estimate the impact of a certain water management measure on both farmer income and the health of riparian vegetation. All these problem fields are embedded in complex human-environment systems. Often, the environmental system itself is not well understood (e.g. how the riparian vegetation reacts to changes in river flow dynamics). Even more often, there is significant uncertainty about the interactions between humans and the environment or about the human system component that is relevant for the environmental system under consideration (e.g. how actions of farmers change in response to water pricing).

To better understand human-environment systems and to support the identification of sustainable management strategies, knowledge of multiple scientific disciplines and diverse stakeholders from various societal sectors has to be integrated (Bergmann et al., 2010). A good system understanding ("system knowledge"), however, is not sufficient for sustainable environmental management that generally requires the endorsement and implementation of management measures by a multitude of stakeholders. In addition, knowledge about the different problem perspectives, values, and goals of the stakeholders ("target knowledge" according to CASS-ProClim, 1997) needs to be generated and integrated, as well as knowledge about how to achieve common goals ("transformation knowledge", CASS-ProClim, 1997). Generation of these three types of knowledge, if done jointly by scientists and stakeholders, can be regarded as "post-normal science" (Funtowicz \& Ravetz, 1991) and has more recently been referred to as "participatory integrated assessment" (Salter, Robinson, \& Wiek, 2010; de Kraker, Kroeze, \& Kirschner, 2011) or "transdisciplinary research" (Hirsch Hadorn et al., 2008; Mobjörk, 2010; Siew \& Döll, 2012). An important goal of transdisciplinary research is social learning of the participants of the joint research process (Giampietro, 2002; Reed et al., 2010). 
To do transdisciplinary research, appropriate methods for supporting joint problem identification, problem analysis, and strategy development have to be identified. Modeling is an appropriate and widely used method in environmental sciences and management, as knowledge about the complex human-environment system has to be integrated. To truly support transdisciplinary research, a relatively simple modeling approach is required. The approach should be able to (1) represent and integrate knowledge from diverse disciplines and spheres, (2) explicitly support the inclusion of stakeholder knowledge and perspectives, and (3) take into account the uncertainty of knowledge.

Bayesian Networks (BNs) fulfill these requirements. BNs have already been used in support of environmental management, in a few cases also in participatory settings where stakeholders were involved in the modeling process beyond the discussion of modeling results. In their literature review on the application of BNs in environmental modeling for the time period 1990-2010, Aguilera, A. Fernández, R. Fernández, Rumí and Salmerón (2011) found that less than 5\% of all identified applications of BNs were in the field of environmental sciences. Uusitalo (2007) reviewed the advantages as well as the challenges of using BNs in environmental modeling and summarized the state of the art of applying BNs. She concluded that BNs are "a useful addition to the toolkit of environmental scientists, especially if their work is related to environmental management". Introducing a special issue on BNs in environmental and resource management, Barton et al. (2012) showed how BN modeling can be adapted to the structure of the problem of interest and stated that BNs have been most widely used in support of mid-to-long-term strategic decision-making at the scale of e.g. catchments or habitats. Castelletti and Soncini-Sessa (2007) considered the integration of BN modeling into a participatory planning process and discussed the specific limitations of BNs in water resources management. Comprehensive guidelines on the application of BNs in support of participatory planning were provided by Cain (2001), Bromley (2005) and Pollino and Henderson (2010).

In this review, we aim at synthesizing the knowledge about application and applicability of BNs as a participatory modeling tool in transdisciplinary research. We wish to provide a solid knowledge basis for researchers (with experience in either BNs or participatory methods) and practitioners who consider using BNs in participatory processes. In section 2, we give a short introduction into BNs. In section 3, we review literature on the application of BNs as a participatory modeling approach in support of environmental management. We provide recommendations on how to apply BNs as a participatory modeling tool in section 4 . This is followed, in section 5, by summarizing strengths and limitations of BNs. Finally, we draw conclusions.

\section{Bayesian Networks}

A BN is a model of a selected real system that represents the system's components and relations in the form of a probabilistic causal network. The terms Bayesian Network, Bayesian Belief Network, belief networks and Bayes net are synonyms (Charniak, 1991; Henriksen, Rasmussen, Brandt, von Bülow, \& Jensen, 2007).

\subsection{Elements of Bayesian Networks}

BNs consist of three elements (Cain, 2001): (1) System variables referred to as nodes and visualized as boxes, (2) Causal relationships between these nodes visualized as directed links which point from cause to effect, and (3) A set of (conditional) probabilities, for each node, defining the strength of the causal relationships. Figure 1 is an example of a simple BN (network structure and states of the variables) that models the decision of a reviewer to accept or reject a scientific paper. The diagram indicates that the system variable "Reviewer's decision" is influenced by the "Quality of the paper" as well as by the "Weather conditions" which influence the reviewer's mood and thus decision. The influences are depicted as causal links. In this case, the nodes "Quality of the paper" and "Weather conditions" are the parent nodes of "Reviewer's decision", while "Reviewer's decision" is the child node of the two influencing nodes. 


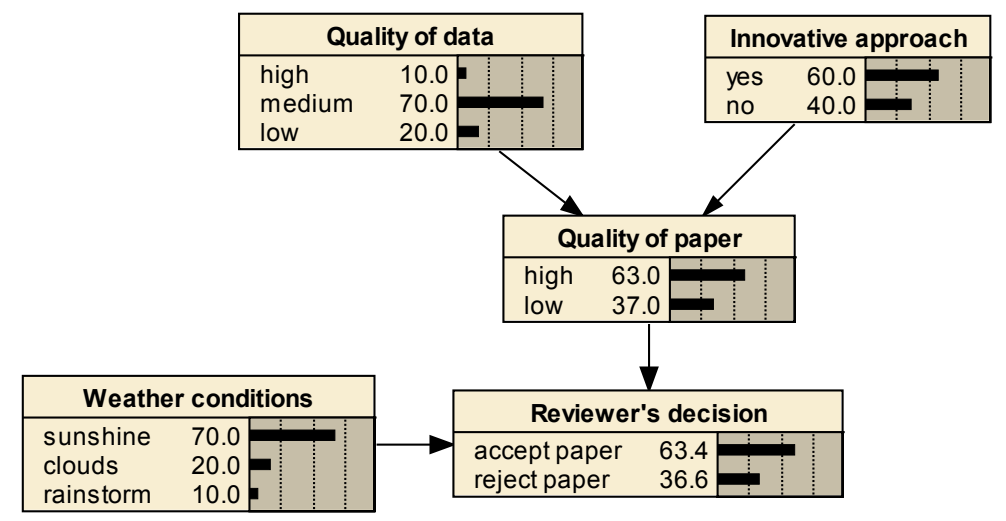

Figure 1. A simple BN "Reviewer's decision”

Nodes without parent nodes, such as "Quality of data", "Innovative approach", and "Weather conditions", are called root nodes. Nodes without child nodes, such as "Reviewer's decision", are called leaf nodes. Root nodes represent the input variables, while leaf nodes constitute the output variables of the BN (Castelletti \& Soncini-Sessa, 2007).

Variables (i.e. nodes) can be either continuous or discrete (as in Figure 1), and in most BN applications, discrete variables are described by a limited number of discrete states (e.g. three in the cases of "Weather conditions"). States for discrete nodes can either be (1) labels, e.g. "low, high", (2) numbers, (3) intervals, or (4) in Boolean form (e.g. "yes, no") (Bromley, 2005). The states must encompass all possible conditions and must be mutually exclusive. As BNs are directed acyclic graphs, feedback loops are not possible in the networks.

For each child node, conditional probability tables (CPTs) need to be defined. A CPT expresses the probability for the states of a child node, given the states of its parent nodes. The rows of the CPT can be read as "if-then-sentences". In our example, the CPT of "Reviewer's decision" reveals that "If the quality of the paper is high and the sun is shining, then the paper will be accepted with a probability of 95\%" (Figure 2). The CPT shows the strengths of the causal relationships, with the "Quality of the paper" having a much stronger impact on the decision than the "Weather conditions".

\begin{tabular}{|ll||lc|}
\hline Quality of paper & Weather conditions & \multicolumn{2}{|c|}{ accept paper reject paper } \\
\hline high & sunshine & 95 & 5 \\
high & clouds & 90 & 10 \\
\hline high & rainstorm & 85 & 15 \\
\hline low & sunshine & 15 & 85 \\
\hline low & clouds & 10 & 90 \\
\hline Low & rainstorm & 5 & 95 \\
\hline
\end{tabular}

Figure 2. Conditional probability table of node "Reviewer's decision"

Root nodes are quantified by unconditional probability tables which can represent observations, scenarios, or potential actions such as management interventions (Bromley, 2005). If root nodes are used to represent different scenarios of the future, the states can also be described with respect to the current conditions, for example with labels "lower than today, like today, higher than today" (Cain, 2001).

\subsection{Entering Data into the Network}

Both the CPTs and the network structure can be automatically learned from data. In problem fields typically assessed by transdisciplinary research, however, not enough data is available for automatic generation of the network structure. The network structure, including the definition of the states, is developed together with stakeholders or based on information gained from literature. In the next step, unconditional probability tables of the root nodes and the CPTs are developed using data obtained from different sources. These include stakeholder/expert knowledge, literature information, observational or statistical data, or output from more detailed numerical models (e.g. Steventon, 2008). 


\subsection{Top-down and Bottom-Up Modeling}

Bayesian networks can either be used "top-down" for predictive purposes or "bottom-up" for diagnostic purposes (Castelletti \& Soncini-Sessa, 2007). Top-down modeling or downward propagation refers to the calculation of the probability distributions of all child nodes in response to the probability distributions of the root nodes, as a function of the network structure and the CPTs. Referring to Figure 1, the probability distributions for "Quality of paper" and "Reviewer's decision" were calculated by the BN modeling software, while the probability distributions of the three root nodes had been set before. If it is known, for example, that the sun is shining during the review process, the probability of "sunshine" of the root node "Weather conditions" can be set to 1 or $100 \%$ and a higher probability for the acceptance of the paper would be calculated, compared to the probality shown in Figure 1. For top-down modeling, the BN modeling software uses the fundamental rule of probability and a joint probability calculation to update the probability distributions for all other nodes (Jensen \& Nielsen, 2007; Pollino \& Henderson, 2010). Top-down modeling is appropriate for impact and scenario analyses, where the BN computes the impact of certain boundary conditions and management decisions on the variables that are planned to be optimized. These boundary conditions and management decisions are often represented by setting the probability of a certain state of a root node to $100 \%$ and their impact is represented by the probability distribution of the child nodes, in particular of the leaf nodes.

Bottom-up modeling or upward propagation refers to the application of the Bayes' rule to update the probability distributions of the parent nodes after a finding that is based on observations was entered for a leaf node or any other child node. Bottom-up modeling is applied for diagnostic purposes, e.g. to assess the likely reasons for an observed environmental pollution. Bottom-up modeling is not equivalent to optimization, i.e. the updated probability distributions of the root nodes cannot be interpreted in terms of decisions that would lead to the observed finding or any desired state of the leaf node. Thus, when applying BNs as participatory modeling tools, they are always used top-down because participatory processes typically aim at a joint strategy development based on impact and scenario analyses.

\subsection{BN Software}

BN modeling is supported by a large number of software packages. Fenton and Neil (2007) compiled a useful list of commercial, open source, and free software tools. Uusitalo (2007) compared various software packages for building BNs in more detail. In the field of environmental modeling, Netica and Hugin are most frequently used (Aguilera et al., 2011).

\section{Recent Applications on Participatory BN Modeling in Environmental Management}

To review recent applications of $\mathrm{BNs}$ in environmental management within a participatory process, we conducted a keyword search for the terms "Bayesian Network" or "Bayesian Belief Network" in the ISI Web of Knowledge, for the period 2001-2011. We included twelve subject areas (Agriculture, Biodiversity Conservation, Ecology, Environmental Sciences, Energy Fuels, Fisheries, Forestry, Geography, Marine Freshwater Biology, Plant Science, Toxicology, and Water Resources) that are related to environmental management. Publications from outside the field of environmental management were excluded.

The resulting 182 publications were categorized and assessed according to the degree of stakeholder or expert involvement in the $\mathrm{BN}$ modeling processes. For this analysis, experts were not distinguished from stakeholders. Categorization was done based on the seven stages of BN modeling process as described by Bromley (2005): (1) Defining problem, context, and stakeholder engagement; (2) Identifying variables, potential actions/scenarios, and indicators to describe the system; (3) Designing the pilot network; (4) Collecting data from all available sources including stakeholders; (5) Defining states of all variables; (6) Constructing CPTs; and (7) Checking network consistency, collecting feedback from stakeholders, and making the final decision. Less than one third of the publications included expert involvement in at least one of the seven steps (Table 1). 
Table 1. Number of publications on BNs in environmental management with different degrees of stakeholder involvement according to Bromley (2005) (ISI Web of Science 2001-2011)

\begin{tabular}{lll}
\hline Category & Category definition & $\begin{array}{l}\text { Number of publications } \\
2001-2011\end{array}$ \\
\hline $\mathrm{P}_{0}$ & $\begin{array}{l}\text { BN generation without stakeholder or scientific expert } \\
\text { involvement }\end{array}$ & 123 \\
& $\begin{array}{l}\text { BN generation with stakeholder or scientific expert } \\
\text { involvement in at least one stage of BN modeling } \\
\text { process }\end{array}$ & \\
$\mathrm{P}_{1-7}$ & & \\
\hline
\end{tabular}

Figure 3 shows the trend of publications on $\mathrm{BN}$ generation with $\left(\mathrm{P}_{1-7}\right)$ and without $\left(\mathrm{P}_{0}\right)$ stakeholder participation. The total number of publications has increased significantly since 2007 , while the proportion of publications on participatory BN modeling remained nearly constant.

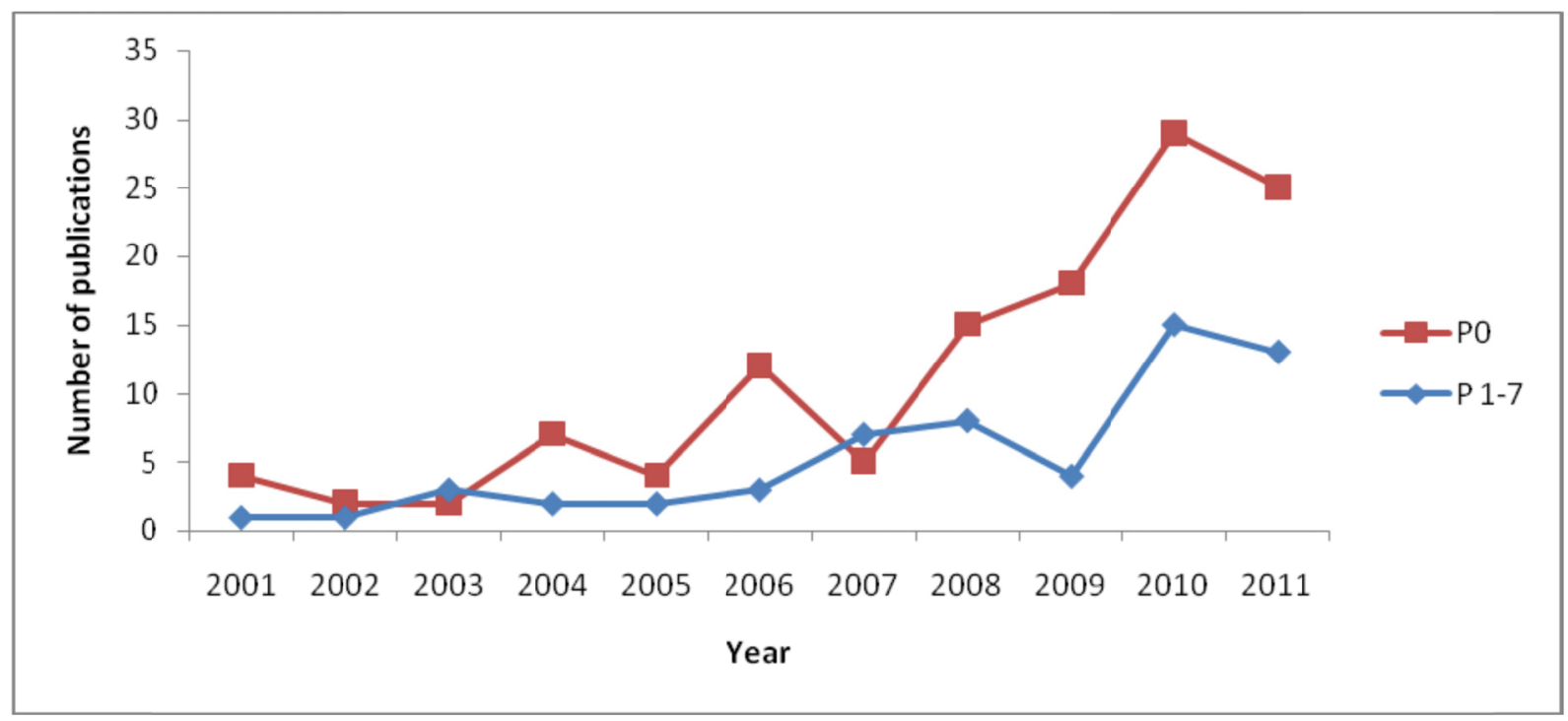

Figure 3. Publications on BN modeling in environmental management from 2001 - 2011, without participation $\left(\mathrm{P}_{0}\right)$ and with stakeholder participation $\left(\mathrm{P}_{2-7}\right)$ (ISI Web of Science; keywords: "Bayesian Network" or "Bayesian Belief Network")

Out of the 59 case studies with stakeholder participation, 30 cases describe stakeholder involvement in at least two stages according to Bromley (2005) (Table A1). The following questions guided our assessment of the identified 30 case studies:

- In which fields of environmental management was BN modeling conducted using a participatory approach?

- How many stakeholders were involved in the participatory modeling process?

- What kinds of stakeholders were involved?

- In which stages of BN modeling were the stakeholders involved?

- How were stakeholders involved?

- What was the information basis used for the construction of CPTs?

- How was the participatory process designed?

- Did stakeholders use the BN as a decision support system (DSS) in practice? 


\subsection{Application of Participatory BN Modeling in Environmental Management}

Participatory BN modeling was mainly applied in water management and conservation management fields, with 15 and 13 cases, respectively (Table A1). In the field of water management, BN modeling was motivated by the requirement for stakeholder involvement stipulated in transnational and national water regulations (Molina, García-Aróstegui, Bromley, \& Benavente, 2011).

\subsection{Number and Type of Stakeholders Involved}

The average number for stakeholders involved in participatory BN modeling was about 10, with a minimum of two stakeholders (Penman, Price, \& Bradstock, 2011) and a maximum of 23 stakeholders (Molina et al., 2011). In four of the participatory modeling processes, only scientific experts were involved (Cyr, Gauthier, Etheridge, Kayahara, \& Bergeron, 2010; Marcot, Steventon, Sutherland, \& McCann, 2006; Peterson, Rieman, Dunham, Fausch, \& Young, 2008; Uusitalo, Kuikka, \& Romakkaniemi, 2005). In one case, this type of stakeholders made it possible to do a review of the developed model by writing a joint publication (Marcot et al., 2006).

In 26 case studies, stakeholder participation went beyond the involvement of scientific experts to take into account the perspectives of stakeholders outside academia. Except in one case (Henriksen et al., 2007, see section 4.1), citizens were not involved. In the case of Borsuk, Stow and Reckhow (2004), citizens' perceptions as derived from interviews into the BN were considered within the participatory modeling process.

\subsection{Stages of BN Modeling Process that Stakeholders were Involved in}

In 17 of the case studies, stakeholders were involved in the three stages of identification of variables, potential actions/scenarios and indicators (stage 2), and the construction of the pilot network (stage 3) as well as CPTs (stage 6) (Table A1). In only seven case studies, stakeholders provided data (stage 4), and in only eight cases stakeholders were consulted to check the consistency of the BN model (stage 7) (Figure 4). None of the case studies reported the involvement of stakeholders in all seven stages (Table A1).

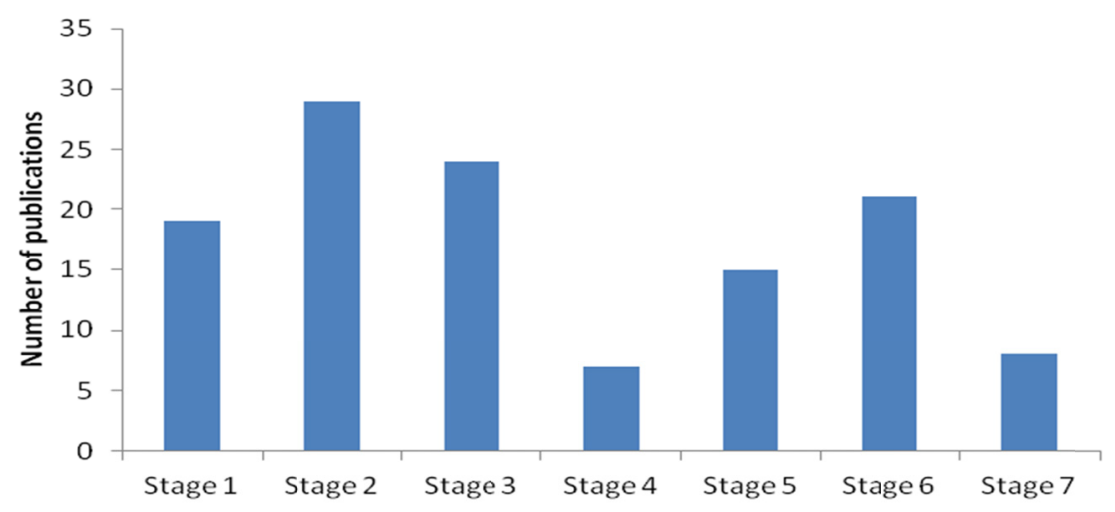

Figure 4. Number of case studies with stakeholder involvement in different stages of participatory BN modeling

The stages are: (1) Defining the problem, context and stakeholder engagement; (2) Identifying variables, potential actions/scenarios and indicators to describe the system; (3) Designing the pilot network; (4) Collecting data from all available sources including stakeholders; (5) Defining states of all variables; (6) Constructing CPTs; (7) Checking network consistency, collecting feedback from stakeholders and making a final decision (Bromley, 2005).

\subsection{Forms of Stakeholder Involvement}

There are six case studies in which different stakeholder groups were involved separately (Cain et al., 2003; Chan, Ross, Hoverman, \& Powell, 2010; Hammond \& O'Brien, 2001; Henriksen et al., 2007; Johnson et al., 2010; Penman et al., 2011). Penman et al. (2011) pointed out that they separated the stakeholders for the workshops to record differing opinions and experiences of each stakeholder. In most of those case studies, different BNs were built. Model-averaging was proposed by Hammond and O'Brien (2001) as a method to integrate different BNs. Chan et al. (2010) described how to merge the conceptual models of three groups (government, NGO and community) into one stakeholder diagram. 


\subsection{Information Basis for the Generation of CPTs}

Most case studies used a combination of different input data to fill in the CPTs (Table A1). Input included outputs of numerical models, stakeholder knowledge, statistical and observational data, and literature findings. In six case studies in the fields of water, conservation and fishery management, the CPTs were derived from stakeholder knowledge only. In ten cases, information from more detailed numerical models was integrated into the BN (Table A1). Peterson et al. (2008) developed in total three BNs with the same network structure but with different CPTs, with one reflecting only expert knowledge. They compared the performance of the models and concluded that the outcomes of the three BNs were consistent.

\subsection{Time and Effort Required}

Most case studies do not provide information about the duration of their participatory processes or the frequency of meetings with stakeholders. Information available ranges from one six-hour workshop (Cain et al., 2003) to three workshops (Henriksen et al., 2007), and to four 1- to 2-day meetings for the basic conceptualization of the BN (Lynam, Drewry, Higham, \& Mitchell, 2010) (Table 2). The most common duration (from the first to the last workshop) of a participatory process was from one (Molina et al., 2011) to one and a half years (Henriksen et al., 2007).

Table 2. Design of participatory process (PP) in three case studies

\begin{tabular}{llll}
\hline $\begin{array}{l}\text { Case study and } \\
\text { field of application }\end{array}$ & $\begin{array}{l}\text { PP period (from } \\
\text { first to last } \\
\text { workshop) }\end{array}$ & Number of workshops in the PP & $\begin{array}{l}\text { Duration of the } \\
\text { workshops }\end{array}$ \\
\hline $\begin{array}{l}\text { Cain et al. (2003), } \\
\text { water management }\end{array}$ & $\begin{array}{l}24.09 .1999- \\
02.10 .1999\end{array}$ & $\begin{array}{l}\text { 3 in total (1 workshop with } \\
\text { government organizations, 1 } \\
\text { workshop with farmers upstream, 1 } \\
\text { workshop with farmers downstream) }\end{array}$ & $\begin{array}{l}\text { workshop 1: 6 h, } \\
\text { workshop 2 \& 3: 4,5 h }\end{array}$ \\
$\begin{array}{l}\text { Henriksen et al. } \\
\text { (2007), water } \\
\text { management }\end{array}$ & $\begin{array}{l}\text { October 2002 - }- \\
\text { 10 in total (5 workshops with } \\
\text { professional group, 5 workshops with } \\
\text { citizen group) }\end{array}$ & $\begin{array}{l}\text { workshop 1 with } \\
\text { professional group: 1 } \\
\text { day }\end{array}$ \\
$\begin{array}{l}\text { Lynam et al. } \\
\text { (2010), water } \\
\text { management }\end{array}$ & $\begin{array}{l}\text { June 2007 - } \\
\text { October 2007 }\end{array}$ & 4 & each 1-2 days \\
\hline
\end{tabular}

In a feasibility study, Lerner, Kumar, Holzkämper, Surridge, and Harris (2011) estimated the manpower resource required for building an integrated catchment management model in a participatory manner. The BN model was proposed as a meta-model for a more complex systems model, to be used by decision-makers. They estimated that 20 person-months of the project team would be necessary for construction, validation, and testing of the BN. Additionally, each stakeholder would have to spend two days, and each domain expert five days, for validation and testing of the $\mathrm{BN}$ model. Much more time was estimated to determine, in the beginning of the process, the scope of the model and to develop a conceptual model (Lerner et al., 2011).

\subsection{BNs Used as DSS}

Most of the studies proposed that BNs have the potential to function as a decision support system (DSS) in practice. Only three case studies (Cain et al., 2003; Inman et al., 2011; Molina et al., 2011) explicitly mentioned the successful implementation of BNs as DSS (Table A1). Ticehurst, Newham, Rissik, Letcher and Jakeman (2007) developed a DSS that was derived from a BN, to evaluate the sustainability of a coastal lake in Australia. They provided training for DSS application to potential users. The low use of BNs as DSS is not specific to BNs but is true for other model-based tools, too; this is due to many reasons (Borowski \& Hare, 2007; Volk, Lautenbach, van Delden, Newham, \& Seppelt, 2009).

\section{Recommendations for the Application of BNs in Participatory Processes}

Mainly based on the 30 reviewed case studies and the three guidelines for participatory BN modeling (Cain, 2001; Bromley, 2005; Pollino \& Henderson, 2010), we now formulate recommendations for participatory BN modeling using the seven stage structure proposed by Bromley (2005). The seven stages and the corresponding 
steps of BN construction and stakeholder involvement are summarized in Table A2. We focus on five of the seven stages of the process, propose an evaluation of participatory $\mathrm{BN}$ modeling and give general recommendations for the whole process.

\subsection{Stage 1 - Defining the Problem, the Context and the Stakeholder Engagement}

In the beginning of the process, participants' expectations should be elicited and openly addressed in order to avoid misunderstandings regarding aims and scopes of a project (Chan et al., 2010). Henriksen et al. (2007) suggested formulating stakeholder involvement plans to make the participatory process more transparent regarding time schedule, expectations, and "rules of the game" (Table A2).

It is important to include a broad range of interest groups in the BN construction in order to integrate different types of knowledge and problem perspectives (Ticehurst et al., 2007). If BNs are planned to be used as a DSS, Cain et al. (2003) suggested the formation of a "core group" of policy makers which sufficiently represent all disciplines (governmental departments). This group should be trained in the application of the BNs and asked to take adequate time to construct a BN in an iterative process and in consultation with external experts. Henriksen et al. (2007) pointed out that a T-organization, i.e. a temporary organisation of representatives from the water authority, experts, stakeholders and citizens, should be formed. In the T-organization, the water authority leads the process and makes the ultimate decisions. At the early stage of the process a "leadership" group identified other stakeholders, initiated the process and developed a first BN to inform other stakeholders about the aim of the process. Later, a "professional" stakeholder group was established out of ten institutions that were involved in groundwater management, as well as an independent "local citizens" group of nine citizens from the area of concern which organized a public meeting of 100 citizens at the local community house. The idea was to take into account the different starting points and to let the "local citizens" group develop their own position without being influenced by the "professional" stakeholder group. The "local citizens" group contributed knowledge to the BN, took part in the evaluation of the BN results and wrote three newsletters to inform the local community.

\subsection{Stage 2 - Identifying Variables, Potential Actions/Scenarios and Indicators to Describe the System}

It is helpful to categorize the variables identified by the stakeholders according to their function in the BN. Cain (2001) distinguished between: (1) Objectives: variables that are to be influenced through management interventions, the key output of BN. (2) Interventions: management options to achieve the objectives. (3) Intermediate variables: factors that connect objectives and interventions. (4) Controlling factors: control the environmental system, but cannot be influenced on considered scale (e.g. rainfall, population growth). (5) Implementing factors: influence the interventions. (6) Additional impacts: variables in addition to objectives that are affected inadvertently by interventions (Figure 5). Molina et al. (2011) proposed five similar categories.

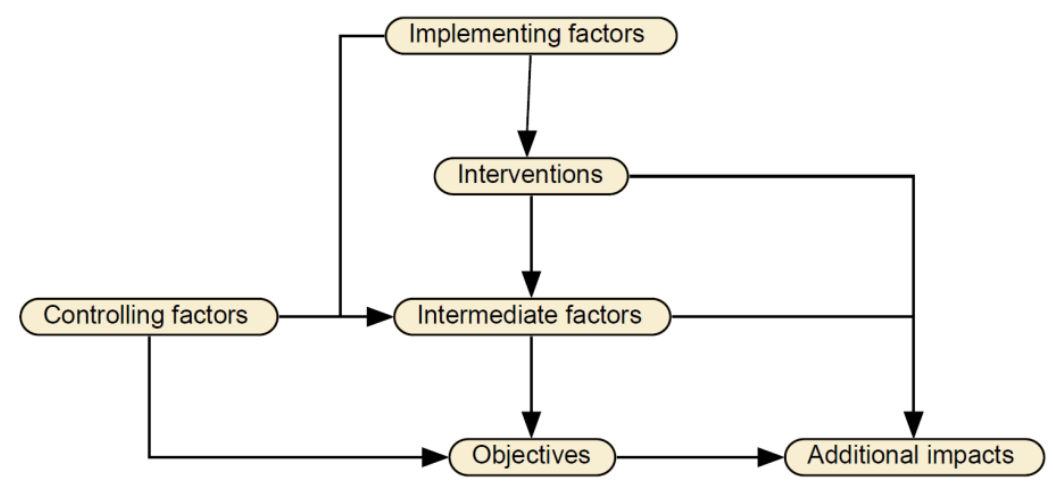

Figure 5. Conceptual model for categorizing variables (Cain, 2001)

The identification of variables should aim at designing a parsimonious model that captures the most relevant processes and causal relations. Therefore, after a broad range of potentially relevant variables has been defined, variables should be reviewed with regard to their relevance but also the possibility of quantifying conditional probabilities. To this end, it is useful to focus, as much as possible, on variables that are controllable or observable at the considered scale (Borsuk, Stow, \& Reckhow, 2004). 


\subsection{Stage 3 - Designing a Pilot Causal Network}

Marcot et al. (2006) advised to start with simpler causal networks when introducing BNs to non-modelers and recommended a thorough documentation of source material and single steps of network construction in order to avoid "battles of the experts" afterwards. Structuring the whole BN as interacting sub-networks simplifies the representation of a complex system (Pollino, White, \& Hart, 2007). For the construction of the sub-networks the stakeholders were divided according to their expertise in the fields covered by the sub-networks (Johnson et al., 2010). The first version of a causal network, when developed with stakeholders, is likely to be overly complex, as each participant might want to see the part of the problem particularly well included that $\mathrm{s} / \mathrm{he}$ is most concerned about; therefore, some simplification is required before CPTs are constructed (Borsuk, Stow, \& Reckhow, 2004).

\subsection{Stage 6 - Construct CPTs}

The question "What is the probability that variable A takes state X given information Y?" (Pollino, Woodberry, Nicholson, Korb, \& Hart, 2007) can be used to elicit stakeholder knowledge for generating CPTs. It is preferable to consult more than one stakeholder for constructing a CPT, to increase the trust in the BN results.

In case of differing estimations of CPTs, CPTs can be averaged (Peterson et al., 2008). If the differences reflect strongly diverging views, the different CPTs should be included explicitly in the BNs. To make two different perspectives on the impact of pesticide application on groundwater quality explicit, Henriksen et al. (2007) added an additional variable with opposing states to the BN such that the results of both perspectives could be compared. In Netica, it is also possible to integrate stakeholders' confidence in their probabilistic estimates. This kind of weighting helps to combine data and stakeholder knowledge for CPT generation (Pollino et al., 2007).

\subsection{Stage 7 - Check Network Consistency, Collect Feedback from Stakeholders and Make Final Decision}

Once the BN has been constructed, it should be tested and reviewed for consistency by an experienced BN modeler. In addition, stakeholders must be involved in testing the BNs to make them credible, either as a group within a workshop or individually (Henriksen et al., 2007; Zorrilla et al., 2009; Penman et al., 2011) (see also Table A2).

After BN validation, the BN can calculate the effects of various scenarios (Carmona, Varela-Ortega, \& Bromley, 2011) or management alternatives (Table A2). This may require the development of qualitative scenarios (Düspohl, Frank, Siew, \& Döll, 2012). To this end, states of root nodes need to be set. The changes in the probability distribution of the leaf node indicate the impact of each scenario. It might be difficult to interpret these calculated outputs. One possibility is to include decision and utility nodes into the BN to make impacts of several management actions comparable. Decision and utility nodes have the advantage to be associated with deterministic costs and benefits (Inman et al., 2011).

\subsection{Evaluating the Success of Participatory BN Modeling}

Given the limited experience with participatory BN modeling, an evaluation of each process is paramount to increase the positive outcomes of participatory BN modeling processes. Unfortunately, very little information on the evaluation of participatory BN modeling processes is available in the literature. Henriksen and Barlebo (2008) did an ex-post evaluation of the participatory BN modeling process described in Henriksen et al. (2007), for which they performed in-depth interviews with two involved water managers. Zorilla et al. (2009) and Inman et al. (2011) developed criteria for the evaluation of participatory BN modeling and asked workshop participants to fill out the questionnaires at the end of their workshop. Martínez-Santos, Henriksen, Zorrilla and Martínez-Alfaro (2010) evaluated BNs by comparing their experiences with participatory BN modeling to experiences with participatory modeling with a groundwater flow model, and found that the modeling approaches are complementary. Questions that can lead through the evaluation are e.g. "In which ways can BNs promote environmental management and allow the management to progress in the face of complexity and uncertainty?", "How do BNs support development of a shared system understanding and provide a structured approach of learning?", and "How can BNs support the transition from the actual traditional management into more adaptive management that is able to deal with changing conditions?" (Henriksen \& Barlebo, 2008). Criteria that should be included in the evaluation are: (1) Structured process to deal with complex planning; (2) Integration of knowledge from diverse sectors; (3) Visual presentation of cross-benefits; (4) Description and decrease of uncertainty in prognosis; (5) Limitation of complexity; (6) Support communication and social learning; (7) Link of research to policy; (8) Identification of lack of knowledge for integration (Henriksen \& Barlebo, 2008; Lerner et al., 2011; Martínez-Santos et al., 2010). 
If the aim of the modeling process is to build a decision support tool for environmental planning, the effectiveness of this decision support tool can be evaluated in addition. Evaluation criteria for this approach are e.g. (1) Organizational receptivity, (2) Reliance on decisions, (3) Technical suitability, (4) Transparency, (5) Learning, (6) Ease of use, or (7) Decision stress (Inman et al., 2011).

\subsection{General Recommendations for Participatory BN-Modeling}

Building of trust is essential for successful participatory modeling with BNs (Chan et al., 2010). Therefore it is necessary to create a respectful atmosphere that enables open discussions. It may be beneficial to involve a professional facilitator to overcome communication problems due to different disciplinary backgrounds (Henriksen et al., 2007; Kragt, Newham, Bennett, \& Jakeman, 2011). In addition, a professional facilitator can handle dominant personalities that might bias results (Penman et al., 2011). Nevertheless, researchers who are experienced in the design of participatory processes and in modeling, are better prepared to guide the participatory modeling process itself.

As most stakeholders and experts may not be familiar with probabilistic reasoning, it is useful to integrate training on Bayesian probabilities and BNs. Hands-on training for stakeholders is necessary to create ownership and trust, and in particular to apply BNs as decision support tools in practice (Henriksen \& Barlebo, 2008). Enabling stakeholders to experiment with BNs may lead to more dynamic, interactive and transparent BN exercises (Henriksen \& Barlebo, 2008), but time constraints of stakeholder involvement may prohibit a more in-depth involvement of stakeholders with BNs. It is desirable to couple BN modeling with Geographical Information Systems to better visualize the spatial dimensions of the modeling results as these are typically of high relevance in environmental management (Henriksen \& Barlebo, 2008).

\section{Strengths and Limitations of Bayesian Networks as Participatory Modeling Tool}

Literature reviews (Uusitalo, 2007; Aguilera et al., 2011), guidelines (Cain, 2001; Bromley, 2005), and various case studies (e.g. Henriksen et al., 2007; Zorrilla et al., 2009) evaluated the strengths and limitations of Bayesian networks for environmental modeling and management. Here, we focus on their strengths and limitations for participatory modeling.

\subsection{Strengths}

- Integration of knowledge from various disciplines and spheres: Knowledge from a wide range of disciplines and spheres can be integrated (e.g. Henriksen et al., 2007) because a BN, with its causal network, allows relating very different variables to each other. The discrete states of the variables allow constructing rather simple probabilistic descriptions of the relation between two variables, which is warranted in case of models which include diverse variables the relation of which is rather uncertain. However, the BN can be made more complex if appropriate. BNs can also help to identify knowledge gaps. Haapasaari and Karjalainen (2010) concluded that the probabilistic language of BNs enabled the integration of social, natural and economic perspectives which in turn facilitated the communication within their multi-disciplinary research group.

- Explicit inclusion of stakeholder knowledge and perspectives: Stakeholders contribute, in a first step, to the construction of the causal net, which allows articulation of their specific knowledge and views on the environmental system under consideration. Regarding the setting of probabilities, the specific Bayesian perspective on probability allows integrating subjective beliefs of stakeholders but also of experts and citizens (Cain et al., 2003; Lynam et al., 2010; Carmona, Varela-Ortega, \& Bromley, 2011).

- Explicit consideration of uncertainty: The probabilistic presentation of knowledge in BNs allows considering uncertainty (which is mostly large in most environmental problems) throughout the analysis process in a transparent way. In addition, it prevents overconfidence in the response to management interventions (Uusitalo, 2007).

- Variety of possible input data: The wide range of input data is a major strength of BNs. Input data, in particular conditional probability tables, may be derived from subjective beliefs, direct measurements or output data from more detailed models, or from a combination of these data sources (Bromley, 2005). In case of appropriate measurements, conditional probability tables can be automatically learnt from data by BN software (Cyr et al., 2010). This variety of input data helps to overcome data scarcity. Bayesian networks can also perform analyses with relatively small and incomplete data sets (Ames, Neilson, Stevens, \& Lall, 2005).

- Transparency: With BNs it is possible to clearly represent expertise, uncertain knowledge or assumptions in a transparent way. Based on four case studies, Bromley (2005) emphasized that decisions which have been 
supported by a participatory BN modeling process are transparent. BNs therefore provide the opportunity to make environmental decision-making more acceptable to the public.

- Short run times: Together with the graphical interface, very short run times of BNs allow users to play with the model and to quickly quantify the impact of certain decisions on the probability distribution of child nodes.

- Communication and learning: Evaluations of BNs as a participatory tool revealed that BNs have the potential to facilitate communication and learning among different stakeholders (Lynam et al., 2010; Zorrilla et al., 2009). The BN diagram (Figure 1) visualizes how systems function, thus facilitating stakeholder learning (Bromley, 2005). Fast run-times of BN models also allow quick recalculations within a stakeholder workshop, thus allowing the participants to learn from modeling results as a group. Learning among stakeholders also includes understanding each other's concerns. BNs are useful for discussions between different disciplines and stakeholder groups (Henriksen et al., 2007; Wang, Robertson, \& Haines, 2009). They can provide a focus for the stakeholder dialogue (Bromley, 2005) and even help to structure the overall participatory process (Zorrilla et al., 2009).

- The availability of user-friendly software packages makes the application of BNs also accessible to non-specialists.

\subsection{Limitations}

- $\quad$ Limited representation of spatial variability, temporal dynamics and feedbacks: As discussed by Pollino and Henderson (2010), static spatial variability (e.g. that different location has different properties) can easily be taken into account by parent nodes that have specific locations as states. Modeling spatial relations and their impact, however, can only be done in a very restrictive way. Temporal dynamics can be represented by combining various BNs to dynamic BNs but the number of time steps is very limited due to excessive computing times (Fenton \& Neil, 2007; Steventon, 2008; Pollino \& Henderson, 2010). Castelletti and Soncini-Sessa (2007) therefore concluded that BNs are not suitable for highly dynamic problems which are often encountered in water resources management. As BNs are acyclic graphs, feedbacks cannot be modeled in a static BN. But if the feedback occurs at the same time-scale as that of the time-scale of a dynamic BN, a feedback loop can be represented (Pollino \& Henderson, 2010).

- Difficulty to elicit conditional probabilities: Populating CPTs is demanding for stakeholders and scientific experts. Eliciting knowledge from scientific experts in a probabilistic form may be difficult if they are not familiar with probabilistic thinking and data analyses. Uusitalo (2007) surmised that scientific experts usually working with observational data may have trouble formulating beliefs without relying on data. Scientific experts usually working with classical statistical analyses may have problems expressing their knowledge in a probabilistic way (Uusitalo, 2007). In addition, people are prone to overconfidence when it comes to probabilistic estimations (Morgan \& Henrion, 1990). Therefore, it is the modeler's responsibility to carefully interpret probability values in CPTs that are very close to zero or one.

- Reliability of expert beliefs and BN modeling results: Quantitative (deterministic or probabilistic) knowledge about causal relations is generally poor for complex human-environment systems that are often of interest in strategic environmental management. In this case, the CPTs are highly uncertain and possibly inaccurate. Even though the stakeholder group agrees on the validity of a jointly developed BN, the computed probability distributions may be incorrect. Keith (1996) pointed out that the number of experts sharing one belief is not necessarily proportional of that belief being correct.

- Cognitive difficulties with probabilities: The probabilistic representation of knowledge is challenging for participatory modeling. Many people have cognitive difficulties to understand probabilities, especially to grasp conditional probabilities (Anderson, 1998). Therefore the network structure needs to be very simple, and the number states should be rather small for participatory modeling (Fenton \& Neil, 2007). The fact that most stakeholders are more familiar with deterministic model results than probability distributions might also constrain the understanding of the model output (Zorrilla et al., 2009).

- $\quad$ Lack of precision of BN models and results: The use of a small number of states for discrete variables, such as "low, medium, high" necessarily leads to an imprecise and vague representation of the system under consideration, and to results that may be difficult to interpret. This can only be overcome to a certain extent by defining numerical boundaries to terms like "low", e.g. related to a certain water quality norm. To avoid this lack of precision, Borsuk, Schweizer and Reichert (2012) chose to use continuous variables but this is only possible in case of well-researched causal relationships. 


\section{Conclusions}

The number of participatory modeling applications of BNs in environmental management is still small. Nevertheless, the 30 reviewed case studies have shown that BN modeling can be successfully applied within a participative process. Together with the guidelines of Cain (2001), Bromley (2005) and Pollino and Henderson (2010), the case studies form a very useful information base for new projects that wish to support transdisciplinary knowledge integration by participatory BN modeling.

Many features make BNs particularly suitable for supporting the identification of sustainable management strategies in problem fields related to complex human-environment systems. Nevertheless, a thorough contemplation of the balance of strengths and limitations of BNs in the specific problem context is recommended before $\mathrm{BN}$ modeling is selected as a participatory modeling approach. To allow for a better representation and visualization of spatial heterogeneity, which is required for supporting land and water management, coupling of BNs to Geographical Information Systems is recommended. To at least partially overcome the limitations of $\mathrm{BNs}$ related to the lack of precision and accuracy, $\mathrm{BN}$ models can be combined with more detailed models. While the BN serves to represent the total human-environment system of interest, more detailed models for sub-domains for which better quantitative knowledge exists are coupled to certain BN nodes. Depending on the location of the coupling nodes within the BN, the detailed model can be used to construct a CPT, or the probability distribution computed by a BN can serve to define the input to a detailed model. For example, the BN may be used to quantify the probability distribution of pollutant emissions under certain scenarios of external driving forces and management options, while the computed emissions scenarios are used, by a soil and groundwater transport model, to compute pollutant concentrations at a drinking water well. With such a coupling of BN and detailed model, the output of the detailed model is more precise then the results of the BN could be, while it is more relevant than it could be without the emissions scenarios derived by the $\mathrm{BN}$.

We conclude that participatory modeling of human-environment systems with BNs has the potential to become a core method of transdisciplinary research and knowledge integration in environmental management. We therefore recommend that environmental scientific experts and managers get acquainted with BNs at least on a general level, and consider their use in transdisciplinary and participatory processes.

\section{Acknowledgments}

We thank two anonymous reviewers for their thoughtful comments. This research was partially funded by the German Federal Ministry of Education and Research (BMBF).

\section{References}

Aguilera, P. A., Fernández, A., Fernández, R., Rumí, R., \& Salmerón, A. (2011). Bayesian networks in environmental modelling. Environmental Modelling \& Software, 26, 1376-1388. http://dx.doi.org/10.1016/j.envsoft.2011.06.004

Ames, D. P., Neilson, B. T., Stevens, D. K., \& Lall, U. (2005). Bayesian network modeling of watershed management decisions. Journal of Hydroinformatics, 7, 267-282. Retrieved from http://www.iwaponline.com/jh/007/0267/0070267.pdf

Anderson, J. L. (1998). Embracing uncertainty: The interface of Bayesian statistics and cognitive psychology. Conversation Ecology, 2(1). Retrieved from http://www.consecol.org/vol2/iss1/art2

Barton, D. N., Kuikka, S., Varis, O., Uusitalo, L., Henriksen H. J., Borsuk M., ... Linnelly, J. D. C. (2012). Bayesian Networks in Environmental and Resource Management. Integrated Environmental Assessment and Management, 8, 418-429. http://dx.doi.org/10.1002/ieam.1327

Bashari, H., Smith, C., \& Bosch, O. J. H. (2008). Developing decision support tools for rangeland management by combining state and transition models and Bayesian belief networks. Agricultural Systems, 99, 23-34. http://dx.doi.org/10.1016/j.agsy.2008.09.003

Bergmann, M., Jahn, T., Knobloch, T., Krohn, W., Pohl, C., \& Schramm, E. (2010). Methoden transdisziplinärer Forschung. Ein Überblick mit Anwendungsgebieten. Frankfurt/New York: Campus Verlag.

Borowski, I., \& Hare, M. (2006). Exploring the gap between water managers and researchers: Difficulties of model-based tools to support practical water management. Water Resources Management, 21, 1049-1074. http://dx.doi.org/10.1007/s11269-006-9098-z 
Borsuk, M. E., Stow, C. A., \& Reckhow, K. H. (2004). A Bayesian network of eutrophication models for synthesis, prediction, and uncertainty analysis. Ecological Modelling, 173, 219-239. http://dx.doi.org/10.1016/j.ecolmodel.2003.08.020

Borsuk, M. E., Schweizer, S., \& Reichert, P. (2012). A Bayesian Network model for integrative river rehabilitation planning and management. Integrated Environmental Assessment and Management, 8, 462-472. http://dx.doi.org/10.1002/ieam.233

Bromley, J. (2005). Guidelines for the use of Bayesian networks as a participatory tool for Water Resource Management. Centre for Ecology and Hydrology. Retrieved from http://nora.nerc.ac.uk/3300/1/MERITGuidelinesplusApp.pdf

Cain, J. (2001). Planning improvements in natural resources management. Guidelines for using Bayesian networks to support the planning and management of development programmes in the water sector and beyond. Centre for Ecology and Hydrology. Retrieved from http://64.40.97.24/downloads/BBN\%20Guidelines\%20-\%20Cain.pdf

Cain, J., Jinapala, K., Makin, I., Somaratna, P., Ariyaranta, B., \& Perera, L. (2003). Participatory decision support for agricultural management. A case study from Sri Lanka. Agricultural Systems, 76, 457-482. doi:10.1016/S0308-521X(02)00006-9

Carmona, G., Varela-Ortega, C., \& Bromley, J. (2011). The use of participatory object-oriented Bayesian Networks and agro-economic models for groundwater management in Spain. Water Resources Management, 25, 1509-1524. http://dx.doi.org/10.1007/s11269-010-9757-y

CASS/ProClim. (1997). Research on Sustainability and Global Change: Visions in Science Policy by Swiss Researchers. ProClim Forum für Klima und Global Change, Bern: Schweizerische Akademie der Naturwissenschaften (SANW).

Castelletti, A., \& Soncini-Sessa, R. (2007). Bayesian Networks and participatory modelling in water resource

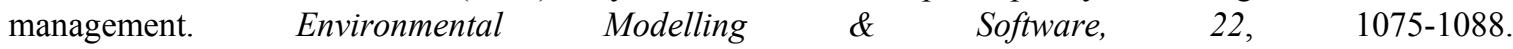
http://dx.doi.org/10.1016/j.envsoft.2006.06.003

Chan, T., Ross, H., Hoverman, S., \& Powell, B. (2010). Participatory development of a Bayesian network model for catchment-based water resource management. Water Resources Research, 46(7), 1-12. http://dx.doi.org/10.1029/2009WR008848

Charniak, E. (1991). Bayesian Networks without tears. AI Magazine, 12, 50-63.

Cyr, D., Gauthier, S., Etheridge, D. A., Kayahara, G. J., \& Bergeron, Y. (2010). A simple Bayesian Belief Network for estimating the proportion of old-forest stands in the Clay Belt of Ontario using the provincial forest inventory. Canadian Journal of Forest Research, 40, 573-584. http://dx.doi.org/10.1139/X10-025

de Kraker, J., Kroeze, C., \& Kirschner, P. (2011). Computer models as social learning tools in participatory integrated assessment. International Journal of Agricultural Sustainability, 9, 297-309.

Düspohl, M., Frank, S., Siew, T. F., \& Döll, P. (2012). Transdisciplinary research for supporting environmental management. In R. Seppelt, A. A. Voinov, S. Lange, \& D. Bankamp (eds.). International Environmental Modelling and Software Society (iEMSs) 2012 - International Congress on Environmental Modelling and Software Managing Resources of a Limited Planet, Sixth Biennial Meeting, Leipzig, Germany, 01-05 July 2012. http://www.iemss.org/society/index.php/iemss-2012-proceedings

Fenton, N., \& Neil, M. (2007). Managing Risk in the Modern World: Applications of Bayesian Networks. London: London Mathematical Society. $\quad$ Retrieved from http://www.agenarisk.com/resources/apps_bayesian_networks.pdf

Funtowicz, S. O., \& Ravetz, J. R. (1991). A new scientific methodology for global environmental issues. In R. Costanza (Ed.), Ecological Economics: The Science and Management of Sustainability (pp.137-152). New York: Columbia University Press.

Giampietro, M. (2002). Complexity and Scales: The Challenge for Integrated Assessment. Integrated Assessment, 3, 247-265. http://dx.doi.org/10.1076/iaij.3.2.247.13568

Haapasaari, P., \& Karjalainen, T. P. (2010). Formalizing expert knowledge to compare alternative management plans: Sociological perspective to the future management of Baltic salmon stocks. Marine Policy, 34, 477-486. http://dx.doi.org/10.1016/j.marpol.2009.10.002 
Haapasaari, P., Michielsens, C. G. J., Karjalainen, T. P., Reinikainen, K., \& Kuikka, S. (2007). Management measures and fishers' commitment to sustainable exploitation: A case study of Atlantic salmon fisheries in the Baltic Sea. ICES Journal of Marine Science, 64, 825-833. http://dx.doi.org/10.1093/icesjms/fsm002

Hamilton, G. S., Fielding, F., Chiffings, A. W., Hart, B. T., \& Johnstone, R. W. (2007). Investigating the use of a Bayesian Network to model the risk of Lyngbya majuscula bloom initiation in Deception Bay, Queensland. Human and Ecological Risk Assessment, 13, 1271-1287. http://dx.doi.org/10.1080/10807030701655616

Hammond, T., \& O'Brien, C. M. (2001). An application of the Bayesian approach to stock assessment model uncertainty. ICES Journal of Marine Science, 58, 648-656. http://dx.doi.org/10.1006/jmsc.2001.1051

Helle, I., Lecklin, T., Jolma, A., \& Kuikka, S. (2011). Modeling the effectiveness of oil combating from an ecological perspective - A Bayesian network for the Gulf of Finland; the Baltic Sea. Journal of Hazardous Materials, 185, 182-192. http://dx.doi.org/10.1016/j.jhazmat.2010.09.017

Henriksen, H. J., \& Barlebo, H. C. (2008). Reflections on the use of Bayesian belief networks for adaptive management. Journal of Environmental Management, 88, 1025-1036. http://dx.doi.org/10.1016/j.jenvman.2007.05.009

Henriksen, H. J., Rasmussen, P., Brandt, G., von Bülow, D., \& Jensen, F. V. (2007). Public participation modelling using Bayesian networks in management of groundwater contamination. Environmental Modelling \& Software, 22, 1101-1113. http://dx.doi.org/10.1016/j.envsoft.2006.01.008

Hirsch Hadorn, G., Hoffmann-Riem, H., Biber-Klemm, S., Grossenbacher-Mansuy, W., Joye, D., Pohl, C., ... Zemp, E. (2008). Handbook of Transdisciplinary Research. Springer.

Inman, D., Blind, M., Ribarova, I., Krause, A., Roosenschoon, O., Kassahun, A., ... Jeffrey, P. (2011). Perceived effectiveness of environmental decision support systems in participatory planning: Evidence from small groups of end-users. Environmental Modelling \& Software, 26, 302-309. http://dx.doi.org/10.1016/j.envsoft.2010.08.005

Jensen, F. V., \& Nielsen, T. D. (2007). Bayesian Networks and Decision Graphs. Pattern Recognition. Berlin: Springer. http://dx.doi.org/10.1007/978-0-387-68282-2

Johnson, S., Mengersen, K., de Waal, A., Marnewick, K., Cilliers, D., Houser, A. M., \& Boast, L. (2010). Modelling cheetah relocation success in southern Africa using an iterative Bayesian Network development Cycle. Ecological Modelling, 221, 641-651. http://dx.doi.org/10.1016/j.ecolmodel.2009.11.012

Keith, D. W. (1996). When is it appropriate to combine expert judgments? Climatic Change, 33, 139-143. http://dx.doi.org/10.1007/BF00140244

Kragt, M. E., Newham, L. T. H., Bennett, J., \& Jakeman, A. J. (2011). An integrated approach to linking economic valuation and catchment modelling. Environmental Modelling \& Software, 26, 92-102. http://dx.doi.org/10.1016/j.envsoft.2010.04.002

Lecklin, T., Ryömä, R., \& Kuikka, S. (2011). A Bayesian network for analyzing biological acute and long-term impacts of an oil spill in the Gulf of Finland. Marine Pollution Bulletin, 62, 2822-2835. http://dx.doi.org/10.1016/j.marpolbul.2011.08.045

Lerner, D. N., Kumar, V., Holzkämper, A., Surridge, B. W. J., \& Harris, B. (2011). Challenges in developing an integrated catchment management model. Water and Environment Journal, 25, 345-354. http://dx.doi.org/10.1111/j.1747-6593.2010.00229.x

Lynam, T., Drewry, J., Higham, W., \& Mitchell, C. (2010). Adaptive modelling for adaptive water quality management in the Great Barrier Reef region, Australia. Environmental Modelling \& Software, 25, 1291-1301. http://dx.doi.org/10.1016/j.envsoft.2009.09.013

Marcot, B. G., Steventon, J. D., Sutherland, G. D., \& McCann, R. K. (2006). Guidelines for developing and updating Bayesian belief networks applied to ecological modeling and conservation. Canadian Journal of Forest Research, 36, 3063-3074. http://dx.doi.org/10.1139/X06-135

Martínez-Santos, P., Henriksen, H. J., Zorrilla, P., \& Martínez-Alfaro, P. E. (2010). Comparative reflections on the use of modelling tools in conflictive water management settings: The Mancha Occidental aquifer, Spain. Environmental Modelling \& Software, 25, 1439-1449. http://dx.doi.org/10.1016/j.envsoft.2008.11.011

McCloskey, J. T., Lilieholm, R. J., \& Cronan, C. (2011). Using Bayesian belief networks to identify potential compatibilities and conflicts between development and landscape conservation. Landscape and Urban Planning, 101, 190-203. http://dx.doi.org/10.1016/j.landurbplan.2011.02.011 
Mobjörk, M. (2010). Consulting versus participatory transdisciplinarity: A refined classification of transdisciplinary research. Futures, 42, 866-873. http://dx.doi.org/10.1016/j.futures.2010.03.003

Molina, J. L., García-Aróstegui, J. L., Bromley, J., \& Benavente, J. (2011). Integrated Assessment of the European WFD Implementation in extremely overexploited aquifers through participatory modelling. Water Resource Management, 25, 3343-3370. http://dx.doi.org/10.1007/s11269-011-9859-1

Morgan, M. G., \& Henrion, M. (1990). Uncertainty - A Guide to Dealing with Uncertainty in Quantitative Risk and Policy Analysis. Cambridge: Cambridge University Press. http://dx.doi.org/10.1017/CBO9780511840609

Penman, T. D., Price, O., \& Bradstock, R. A. (2011). Bayes Nets as a method for analysing the influence of management actions in fire planning. International Journal of Wildland Fire, 20, 909-920. http://dx.doi.org/10.1071/WF10076

Peterson, D. P., Rieman, B. E., Dunham, J. B., Fausch, K. D., \& Young, M. K. (2008). Analysis of trade-offs between threats of invasion by nonnative brook trout (Salvelinus fontinalis) and intentional isolation for native westslope cutthroat trout (Oncorhynchus clarkii lewisi). Canadian Journal of Fisheries and Aquatic Sciences, 65, 557-573. http://dx.doi.org/10.1139/F07-184

Pollino, C. A., \& Henderson, C. (2010). Bayesian networks: A guide for their application in natural resource management and policy. Landscape Logic, Technical Report 14, Australian Government - Department of the Environment, Water, Heritage and the Arts. Retrieved from http://www.landscapelogicproducts.org.au/site/system/files/35/original/No_14_BNs_a_resource_guide.pdf? 1275920191

Pollino, C., White, A. K., \& Hart, B. T. (2007). Examination of conflicts and improved strategies for the management of an endangered Eucalypt species using Bayesian networks. Ecological Modelling, 201, 37-59. http://dx.doi.org/10.1016/j.ecolmodel.2006.07.032

Pollino, C. A., Woodberry, O., Nicholson, A., Korb, K., \& Hart, B. T. (2007). Parameterisation and evaluation of a Bayesian network for use in an ecological risk assessment. Environmental Modelling \& Software, 22, 1140-1152. http://dx.doi.org/10.1016/j.envsoft.2006.03.006

Reed, M. S., Evely, A. C., Cundill, G., Fazey, I., Glass, J., Laing, A., ... Stringer, L. C. (2010). What is Social Learning? Ecology and Society, 15(4), r1. Retrieved from http://www.ecologyandsociety.org/vol15/iss4/resp1/

Salter, J., Robinson, J., \& Wiek, A. (2010). Participatory methods of integrated assessment - A review. Wiley Interdisciplinary Reviews: Climate Change, 1, 697-717. http://dx.doi.org/10.1002/wcc.73

Siew, T. F., \& Döll, P. (2012). Transdisciplinary research for supporting the integration of ecosystem services into land and water management in the Tarim River Basin, Xinjiang, China. Journal of Arid Land, 4, 196-210. http://dx.doi.org/10.3724/SP.J.1227.2012.00196

Steventon, J. D. (2008). Conservation of marbled murrelets in British Columbia. In Pourret, O., Naim, P., \& B. Marcot (Eds.), Bayesian Networks: A Practical Guide to Applications (pp. 127-148). Chichester: John Wiley and Sons.

Ticehurst, J. L., Newham, L. T. H., Rissik, D., Letcher, R. A., \& Jakeman, A. J. (2007). A Bayesian network approach for assessing the sustainability of coastal lakes in New South Wales, Australia. Environmental Modelling \& Software, 22, 1129-1139. http://dx.doi.org/10.1016/j.envsoft.2006.03.003

Uusitalo, L. (2007). Advantages and challenges of Bayesian networks in environmental modelling. Ecological Modelling, 203(3-4), 312-318. http://dx.doi.org/10.1016/j.ecolmodel.2006.11.033

Uusitalo, L., Kuikka, S., \& Romakkaniemi, A. (2005). Estimation of Atlantic salmon smolt carrying capacity of rivers using expert knowledge. ICES Journal of Marine Science, 62, 708-722. http://dx.doi.org/10.1016/j.icesjms.2005.02.005

Volk, M., Lautenbach, S., van Delden, H., Newham, L. T. H., \& Seppelt, R. (2009). How can we make progress with decision support systems in landscape and river basin management? Lessons learned from a comparative analysis of four different decision support systems. Environmental Management, 46, 834-849. http://dx.doi.org/10.1007/s00267-009-9417-2 
Wang, Q. J., Robertson, D. E., \& Haines, C. L. (2009). A Bayesian network approach to knowledge integration and representation of farm irrigation: 1. Model development. Water Resources Research, 45(2), 1-18. http://dx.doi.org/10.1029/2006WR005419

Zorrilla, P., Carmona, G., Hera, Á. D., Varela-Ortega, C., Martínez-Santos, P., Bromley, J., \& Henriksen, H. J. (2009). Evaluation of Bayesian Networks in participatory water resources management. Upper Guadiana Basin, Spain. Ecology and Society, 15(3), 12. Retrieved from http://www.ecologyandsociety.org/vol15/iss3/ $\operatorname{art} 12 /$

\section{Appendix}

Table A1. Applications of BNs for participatory modeling in environmental management, 2001-2011. Refer to section 3 regarding the stages of stakeholder involvement

\begin{tabular}{|c|c|c|c|c|}
\hline Case study & $\begin{array}{l}\text { Field of } \\
\text { application }\end{array}$ & $\begin{array}{l}\text { Stages with stakeholder } \\
\text { involvement according to } \\
\text { Bromley (2005) }\end{array}$ & $\begin{array}{l}\text { Derivation of } \\
\text { conditional probability } \\
\text { tables }\end{array}$ & $\begin{array}{l}\text { Using the BN } \\
\text { as DSS in } \\
\text { practice }\end{array}$ \\
\hline Ames et al. $(2005)^{1}$ & $\begin{array}{l}\text { water } \\
\text { management }\end{array}$ & 1,6 & $\begin{array}{l}\text { data, stakeholder } \\
\text { knowledge }\end{array}$ & unknown \\
\hline $\begin{array}{l}\text { Bashari, Smith, \& Bosch } \\
(2008)\end{array}$ & $\begin{array}{l}\text { conservation } \\
\text { Management }\end{array}$ & $2,5,6,7$ & $\begin{array}{l}\text { data, stakeholder } \\
\text { knowledge }\end{array}$ & unknown \\
\hline $\begin{array}{l}\text { Borsuk, Stow, \& Reckhow } \\
\text { (2004) }\end{array}$ & $\begin{array}{l}\text { water } \\
\text { management }\end{array}$ & 2,6 & $\begin{array}{l}\text { data, stakeholder } \\
\text { knowledge, literature }\end{array}$ & unknown \\
\hline Cain et al. (2003) & $\begin{array}{l}\text { water } \\
\text { management }\end{array}$ & $1,2,3,5,6$ & stakeholder knowledge & yes \\
\hline $\begin{array}{l}\text { Carmona, Varela-Ortega, \& } \\
\text { Bromley (2011) }\end{array}$ & $\begin{array}{l}\text { water } \\
\text { management }\end{array}$ & $2,3,5,6,7$ & $\begin{array}{l}\text { numerical models, data, } \\
\text { stakeholder knowledge, } \\
\text { literature }\end{array}$ & unknown \\
\hline Chan et al. (2010) & $\begin{array}{l}\text { water } \\
\text { management }\end{array}$ & $1,2,3,4$ & $\begin{array}{l}\text { numerical models, data, } \\
\text { stakeholder knowledge, } \\
\text { literature }\end{array}$ & unknown \\
\hline Cyr et al. (2010) & $\begin{array}{l}\text { conservation } \\
\text { management }\end{array}$ & $2,3,5$ & data & unknown \\
\hline $\begin{array}{l}\text { Haapasaari, Michielsens, } \\
\text { Karjalainen, Reinikainen, \& } \\
\text { Kuikka (2007) }\end{array}$ & $\begin{array}{l}\text { fishery } \\
\text { management }\end{array}$ & $1,2,3,5$ & stakeholder knowledge & no \\
\hline $\begin{array}{l}\text { Hamilton, Fielding, } \\
\text { Chiffings, Hart, \& Johnstone } \\
\text { (2007) }\end{array}$ & $\begin{array}{l}\text { water } \\
\text { management }\end{array}$ & $1,2,3,5,6$ & $\begin{array}{l}\text { numerical models, data, } \\
\text { stakeholder knowledge }\end{array}$ & unknown \\
\hline $\begin{array}{l}\text { Hammond \& O'Brien } \\
(2001)^{1}\end{array}$ & $\begin{array}{l}\text { fishery } \\
\text { management }\end{array}$ & 2,3 & unknown & no \\
\hline $\begin{array}{l}\text { Helle, Lecklin, Jolma, \& } \\
\text { Kuikka (2011) }\end{array}$ & $\begin{array}{l}\text { conservation } \\
\text { management }\end{array}$ & $2,3,6$ & $\begin{array}{l}\text { numerical models, data, } \\
\text { stakeholder knowledge, } \\
\text { literature }\end{array}$ & unknown \\
\hline Henriksen et al. $(2007)^{1}$ & $\begin{array}{l}\text { water } \\
\text { management }\end{array}$ & $1,2,3,4,5,6$ & $\begin{array}{l}\text { data, stakeholder } \\
\text { knowledge, literature }\end{array}$ & unknown \\
\hline Inman et al. (2011) & $\begin{array}{l}\text { water } \\
\text { management }\end{array}$ & $1,2.3,4,7$ & $\begin{array}{l}\text { stakeholder knowledge, } \\
\text { literature }\end{array}$ & yes \\
\hline Johnson et al. (2010) & $\begin{array}{l}\text { conservation } \\
\text { management }\end{array}$ & $1,2,3,5,6,7$ & stakeholder knowledge & unknown \\
\hline Kragt et al. (2011) ${ }^{1}$ & $\begin{array}{l}\text { water } \\
\text { management }\end{array}$ & 2,5 & $\begin{array}{l}\text { numerical models, data, } \\
\text { stakeholder knowledge }\end{array}$ & no \\
\hline $\begin{array}{l}\text { Lecklin, Ryömä, \& Kuikka } \\
\text { (2011) }\end{array}$ & $\begin{array}{l}\text { conservation } \\
\text { management }\end{array}$ & $2,3,6$ & $\begin{array}{l}\text { stakeholder knowledge, } \\
\text { literature }\end{array}$ & unknown \\
\hline Lerner et al. $(2011)^{2}$ & $\begin{array}{l}\text { water } \\
\text { management }\end{array}$ & $1,2,3$ & $\begin{array}{l}\text { numerical models, data, } \\
\text { stakeholder knowledge }\end{array}$ & unknown \\
\hline Lynam et al. (2010) & $\begin{array}{l}\text { water } \\
\text { management }\end{array}$ & $2,3,6$ & $\begin{array}{l}\text { numerical models, data, } \\
\text { literature }\end{array}$ & unknown \\
\hline
\end{tabular}


Table A1. Applications of BNs for participatory modeling in environmental management, 2001-2011. Refer to section 3 regarding the stages of stakeholder involvement (continued)

\begin{tabular}{|c|c|c|c|c|}
\hline Case study & $\begin{array}{l}\text { Field of } \\
\text { application }\end{array}$ & $\begin{array}{l}\text { Stages with stakeholder } \\
\text { involvement according to } \\
\text { Bromley (2005) }\end{array}$ & $\begin{array}{l}\text { Derivation of conditional } \\
\text { probability tables }\end{array}$ & $\begin{array}{l}\text { Using the } \mathrm{BN} \text { as } \\
\text { DSS in practice }\end{array}$ \\
\hline Marcot et al.(2006) & $\begin{array}{l}\text { conservation } \\
\text { management }\end{array}$ & $1,2,3,5,6,7$ & $\begin{array}{l}\text { data, stakeholder } \\
\text { knowledge }\end{array}$ & unknown \\
\hline $\begin{array}{l}\text { Martínez-Santos et al. } \\
(2010)^{2}\end{array}$ & $\begin{array}{l}\text { water } \\
\text { management }\end{array}$ & $1,2,3,4,5,6$ & $\begin{array}{l}\text { numerical models, data, } \\
\text { stakeholder knowledge, } \\
\text { literature }\end{array}$ & no \\
\hline $\begin{array}{l}\text { McCloskey, Lilieholm, } \\
\text { \& Cronan (2011) }\end{array}$ & $\begin{array}{l}\text { conservation } \\
\text { management }\end{array}$ & $2,5,6$ & stakeholder knowledge & unknown \\
\hline Molina et al. (2011) & $\begin{array}{l}\text { water } \\
\text { management }\end{array}$ & $2,3,4,6,7$ & $\begin{array}{l}\text { data, stakeholder } \\
\text { knowledge, literature }\end{array}$ & yes \\
\hline Penman et al. $(2011)^{1}$ & $\begin{array}{l}\text { conservation } \\
\text { management }\end{array}$ & $1,2,3,4,5,6$ & $\begin{array}{l}\text { numerical models, data, } \\
\text { stakeholder knowledge }\end{array}$ & unknown \\
\hline Peterson et al. (2008) & $\begin{array}{l}\text { conservation } \\
\text { management }\end{array}$ & $1,2,3,6$ & $\begin{array}{l}\text { numerical models, data, } \\
\text { stakeholder knowledge }\end{array}$ & unknown \\
\hline Pollino et al. (2007) & $\begin{array}{l}\text { conservation } \\
\text { management }\end{array}$ & $1,2,3,5,6,7$ & $\begin{array}{l}\text { data, stakeholder } \\
\text { knowledge }\end{array}$ & unknown \\
\hline $\begin{array}{l}\text { Pollino, White, \& Hart } \\
\text { (2007) }\end{array}$ & $\begin{array}{l}\text { conservation } \\
\text { management }\end{array}$ & $1,2,3,6$ & $\begin{array}{l}\text { data, stakeholder } \\
\text { knowledge, literature }\end{array}$ & unknown \\
\hline Ticehurst et al. (2007) & $\begin{array}{l}\text { conservation } \\
\text { management }\end{array}$ & $1,2,3$ & $\begin{array}{l}\text { data, stakeholder } \\
\text { knowledge, literature }\end{array}$ & unknown \\
\hline $\begin{array}{l}\text { Uusitalo, Kuikka, \& } \\
\text { Romakkaniemi (2005) }\end{array}$ & $\begin{array}{l}\text { conservation } \\
\text { management }\end{array}$ & $1,2,3,6$ & stakeholder knowledge & unknown \\
\hline $\begin{array}{l}\text { Wang, Robertson, \& } \\
\text { Haines (2009) }\end{array}$ & $\begin{array}{l}\text { water } \\
\text { management }\end{array}$ & $1,2,5$ & $\begin{array}{l}\text { stakeholder knowledge, } \\
\text { literature }\end{array}$ & unknown \\
\hline Zorilla et al. $(2010)^{2}$ & $\begin{array}{l}\text { water } \\
\text { management }\end{array}$ & $1,2,3,4,6,7$ & stakeholder knowledge & unknown \\
\hline
\end{tabular}

${ }^{1}$ Study describes optimization with decision nodes.

${ }^{2}$ Study includes formal evaluation of the application of participatory BN. 
Table A2. Stages and steps of participatory BN construction with stakeholder involvement according to Bromley (2005).

\begin{tabular}{|c|c|c|c|}
\hline & $\begin{array}{l}\text { Definition of } \\
\text { stages }\end{array}$ & Steps in $\mathrm{BN}$ construction & Stakeholder involvement \\
\hline \multirow{4}{*}{1} & \multirow{4}{*}{$\begin{array}{l}\text { define the } \\
\text { problem, the } \\
\text { context and } \\
\text { stakeholder } \\
\text { engagement }\end{array}$} & define objectives & identify and select stakeholders \\
\hline & & delineate geographical area of interest & analyze stakeholder interest, world perception \\
\hline & & define soc. and econom. boundaries & agree on roles and responsibilities \\
\hline & & identify time horizon & agree on stakeholder involvement plan \\
\hline \multirow{4}{*}{2} & \multirow{4}{*}{$\begin{array}{l}\text { identify variables, } \\
\text { potential actions } \\
\text { and indicators to } \\
\text { describe the } \\
\text { system }\end{array}$} & list all factors to be addressed & list stakeholder concerns \\
\hline & & identify key indicators & stakeholders to suggest important indicators \\
\hline & & identify potential actions/scenarios & suggest list of possible actions/scenarios \\
\hline & & identify data sources & stakeholders to identify data sources \\
\hline \multirow{3}{*}{3} & \multirow{3}{*}{$\begin{array}{l}\text { design a pilot } \\
\text { causal network }\end{array}$} & $\begin{array}{l}\text { define input variables and links for the } \\
\text { network }\end{array}$ & $\begin{array}{l}\text { stakeholder interview: receive comments on } \\
\text { the design of the initial network }\end{array}$ \\
\hline & & $\begin{array}{l}\text { design causal network,minimizing the } \\
\text { size of the network and of the required } \\
\text { CPTs) }\end{array}$ & $\begin{array}{l}\text { demonstration including CPTs to illustrate } \\
\text { power of networks }\end{array}$ \\
\hline & & $\begin{array}{l}\text { check consistency, logic \& focus of } \\
\text { network }\end{array}$ & $\begin{array}{l}\text { arrange system of dissemination to } \\
\text { stakeholders and or general public }\end{array}$ \\
\hline \multirow{3}{*}{4} & \multirow{3}{*}{$\begin{array}{l}\text { collect data from } \\
\text { all available } \\
\text { sources including } \\
\text { stakeholders }\end{array}$} & $\begin{array}{l}\text { collect data for each variable and causal } \\
\text { link }\end{array}$ & $\begin{array}{l}\text { individual stakeholder interview: collect data } \\
\text { from individual stakeholders }\end{array}$ \\
\hline & & analyze data & - \\
\hline & & $\begin{array}{l}\text { revise network structure based on data } \\
\text { availability }\end{array}$ & - \\
\hline 5 & $\begin{array}{l}\text { define states for } \\
\text { all variables }\end{array}$ & define states for all variables & $\begin{array}{l}\text { stakeholder interview: input for stakeholders } \\
\text { for states }\end{array}$ \\
\hline \multirow{3}{*}{6} & \multirow{3}{*}{ construct CPTs } & manual entry of CPTs & $\begin{array}{l}\text { individual stakeholder interview: obtain } \\
\text { stakeholder opinion }\end{array}$ \\
\hline & & $\begin{array}{l}\text { automatic learning techniques to } \\
\text { generate CPTs }\end{array}$ & - \\
\hline & & review network and amend as necessary & $\begin{array}{l}\text { individual stakeholder interview: obtain } \\
\text { stakeholder opinion }\end{array}$ \\
\hline \multirow{6}{*}{7} & \multirow{6}{*}{$\begin{array}{l}\text { check network } \\
\text { consistency, } \\
\text { collect feedback } \\
\text { from stakeholders } \\
\text { and make final } \\
\text { decision }\end{array}$} & $\begin{array}{l}\text { check consistency of network: does it } \\
\text { make sense }\end{array}$ & - \\
\hline & & $\begin{array}{l}\text { evaluate feedback from stakeholder and } \\
\text { incorporate if necessary }\end{array}$ & $\begin{array}{l}\text { stakeholder interview: feedback from } \\
\text { stakeholders an review of network }\end{array}$ \\
\hline & & add decision nodes if required & - \\
\hline & & $\begin{array}{l}\text { evaluate/modify/adopt network/ } \\
\text { sensitivity analysis }\end{array}$ & - \\
\hline & & implement BN in DSS if required & - \\
\hline & & alternative options/negotiation/decision & $\begin{array}{l}\text { decision/reporting comments from } \\
\text { stakeholders }\end{array}$ \\
\hline
\end{tabular}

